\title{
Toxic Waste Spilled in Abidjan in 2006: Effects on the Incidence and Prevalence of Malignant Haemopathies in Côte D'Ivoire
}

\author{
N’dhatz Emeraude C1, Packo Dieu-le-veut SS1*, Nanho Danho C1, \\ Kamara Ismael ${ }^{1}$, Bognini $S^{2}$ and Koffi Kouassi G ${ }^{1}$ \\ ${ }^{1}$ Department of Clinical Hematology, University of Felix Houphouet Boigny, Côte \\ d'Ivoire \\ 2Department of Clinical Biology, University of Felix Houphouet Boigny, Côte \\ d'Ivoire
}

\begin{tabular}{|c|}
\hline Research Article \\
Volume 3 Issue 2 \\
Received Date: September 19, 2019 \\
Published Date: October 03, 2019 \\
DoI: $10.23880 /$ hij-16000146 \\
\hline
\end{tabular}

*Corresponding author: Packo Dieu-le-Veut Saint-Cyr Sylvestre, Department of Clinical Hematology, University of Felix Houphouet Boigny, P.0. Box 1439, Abidjan 04, Cote d'Ivoire, Tel: 0022589542209; Email: stcyrpacko@yahoo.fr

\section{Abstract}

Background: August 19, 2006, haematotoxic waste was spilled in the district of Abidjan. We contacted after, the increase of number of patients with haematological malignancies in our department.

Objective: To estimate the prevalence and incidence of haematological malignancies since the spilling of toxic waste in Abidjan.

Materials and Methods: It was a retrospective and descriptive study with duration of three years (from 2007 to 2009) at the department of Clinical hematology in Abidjan. We selected all records of patients between 1999 to 2006, then we included the news cases of hematological malignancies which diagnostic was made from 2007 to 2009. 100 patients had constituted our sample.

Results: 3865 patients were hospitalized during the period from 2007 to 2009, among which 201 cases of haematological malignancies, a prevalence of 5.2\%. There were 100 new cases, an incidence of 33.33 new cases/year. The average age of patients was 34.83 years with extremes of 6 months and 81 years. The majority of patients resided in Abidjan (68\%) and was male. The predominant hematological malignancy was lymphoproliferative syndromes (46,76\%) with an incidence of 15.67 new cases/year. We found 60 cases $(29.85 \%)$ of myeloproliferative syndrome and 47 cases (23.38\%) of acute leukemia with an incidence of 9.67 and 8 new cases/year, respectively.

Conclusion: The number of haematological malignancies seems to increase in Abidjan after the spilling of toxic waste since 2006 in Abidjan. Although this number could be related to the effect of this toxic waste other risk factors should not be completely excluded.

Keywords: Incidence; Prevalence; Haematological Malignancies; Toxic Waste; Abidjan 
Abbreviations: LB: Burkitt Lymphoma; CML: Chronic Myeloid Leukemia.

\section{Introduction}

The health of human is closely related to the environment in which he lives. Thus, haematological malignancies have been found in the survivors of atomic bomb of Hiroshima and Nagasaki [1]. The air we breathe, our food, the electric and electromagnetic object which we currently use is an impact in our health $[2,3]$. There are more than 70,000 chemical compounds commonly used in our environment and whose long-term toxicity is poorly understood [2]. Hematological malignancies admit infectious, immunological, genetic and environmental risk factors. Solvents and herbicides are implicated in the occurrence of non-Hodgkin's Malignant Lymphoma; gasoline, lead and ionizing radiation in the occurrence of leukemia. In addition to these products, hydrogen sulphide, hydrocarbons (benzene and its derivatives) and phenols are hematotoxic at the long term [4]. In 2006, the ship Probo Koala spilled several hundred tons of toxic waste at several sites in Abidjan (Côte d'Ivoire). Immediate signs of intoxication have been observed with also recorded deaths. The expertise carried out on waste reveals the presence of toxic products such as mercaptans and hydrogen sulphide [5]. These products are known for their haematotoxic effects [6]. Since then, the number of patients with haematological malignancies becomes more and more important in our department. The aim of this study was to determine the impact of spills of these toxic wastes on the prevalence and incidence of haematological malignancies in Côte d'Ivoire.

\section{Materials and Methods}

Our study was performed at the department of clinical hematology of Yopougon Teaching Hospital in Abidjan. It was a retrospective and descriptive study concerning the patients with hematological malignancies, hospitalized or followed from January 2007 to December 2009. Diagnostic methods were specific for each disease. The means of diagnostic were histology and immunohistochemistry for lymphomas; immunophenotyping for lymphoproliferative syndrome; conventional cytogenetics for myeloproliferative syndromes, blood count exam and bone marrow examination for leukemia. 201 records were selected among which 100 patients were recruited in our study. Parameters studied were demographic data (age, sex, place of residence, marital status), history of exposure to risk factors such as alcohol, exposures to phytosanitary products and toxic wastes, the notion of blood transfusion and viral infection (HTLV, HIV, HBV, HCV). We also studied data concerning the period of hospitalization and the reason of consultation or hospitalization of each patient. The clinical parameters studied concerned the general state of the patient, the existence or not of the tumor syndrome. As for biological data, we studied the cytological values and characteristics of values of blood count exam, bone marrow exam, the Osteomedullary Biopsy and the lymph node biopsy with histological examination, Immunophenotyping, Cytogenetics, Electrophoresis of the proteins, Targeted protein profile, Immunofluorescence of the proteins Serum, Immunofixation of concentrated urine were also studied to assess the biological evolution of the disease. The data were collected using a survey sheet prepared and standardized. Data analysis was performed using EPIINFO 6.04b. Text entry, tabulation and drawing were done using Word, Excel software.

\section{Results}

During the period from 2007 to 2009, 3865 patients were hospitalized in our department of which 201 cases of hematological malignancies, an overall prevalence of $5.2 \%$. There were 100 new cases, an annual incidence of 33.33 cases /year. All age groups were represented and the majority of our patients resided in Abidjan (Table 1). The highest prevalence and incidence was observed in 2009, three years after the spill of this toxic waste (Table 2 ). We also found that the annual incidence was 46.14 new cases /year between the years 1999 to 2006. For the different nosological groups, the lymphoproliferative syndromes were the most among them the Burkitt lymphoma (LB) was present in $34.04 \%$ of cases. Myeloproliferative syndromes ranked second with 29\% prevalence of chronic myeloid leukemia (CML) (Table 3).

\begin{tabular}{|c|c|}
\hline Variables & Number (\%) \\
\hline Age (Years) & \\
\hline $0-20$ & $30 \%$ \\
\hline $21-60$ & $61 \%$ \\
\hline$>60$ & $9 \%$ \\
\hline Sex & $67 \%$ \\
\hline Male & $33 \%$ \\
\hline Female & \\
\hline Place of residence & $68 \%$ \\
\hline Abidjan & $32 \%$ \\
\hline Outside Abidjan & \\
\hline
\end{tabular}

Table 1: Epidemiological characteristics. 


\begin{tabular}{|c|c|c|}
\hline \multicolumn{2}{|c|}{ Period before and after Spilling of Toxic Waste } \\
\hline Years & Prevalence & Incidence \\
\hline 2007 & $4 \%$ & $23 \%$ \\
\hline 2008 & $4,83 \%$ & $43 \%$ \\
\hline 2009 & $6,64 \%$ & 33,33 new case/year \\
\hline $\mathbf{2 0 0 7 - 2 0 0 9}(\mathbf{n = 1 0 0 )}$ & $5,21 \%$ & 46,14 new case/year \\
\hline $\mathbf{1 9 9 9 - 2 0 0 6}(\mathbf{n = 3 2 3})$ & $8,47 \%$ & $\mathbf{\%}$ \\
\hline \multicolumn{2}{|c|}{ Nosological Groups } \\
\hline Haemopathies malignancies & Frequency & 5,47 \\
\hline Lymphoprolifératives Syndrome (n=47) & 11 & 7,46 \\
\hline 2007 & 15 & 10,44 \\
\hline 2008 & 21 & 3,4 \\
\hline 2009 & & 4,47 \\
\hline Myéloprolifératives Syndrome (n=29) & 7 & 6,46 \\
\hline 2007 & 9 & 2,48 \\
\hline 2008 & 13 & 3,98 \\
\hline 2009 & & 5,47 \\
\hline 2007 & 5 & \\
\hline 2008 & 8 & \\
\hline 2009 & 11 & \\
\hline Acute leukemia (n=24) & & \\
\hline
\end{tabular}

Table 2: Prevalence and incidence of haemopathies malignancies.

\begin{tabular}{|c|c|c|c|c|c|c|}
\hline \multicolumn{7}{|c|}{ Lymphoproliferatves Syndrome (LPS) } \\
\hline & LPS & $\begin{array}{l}\text { Burkitt's } \\
\text { Lymphoma }\end{array}$ & $\begin{array}{l}\text { Non-Hodgkin's } \\
\text { malignant } \\
\text { lymphomas }\end{array}$ & $\begin{array}{l}\text { Multiple } \\
\text { Myeloma }\end{array}$ & $\begin{array}{l}\text { Hodgkin's } \\
\text { Lymphoma }\end{array}$ & $\begin{array}{l}\text { Chronic Lymphoid } \\
\text { Leukemia }\end{array}$ \\
\hline \multicolumn{7}{|c|}{ Prevalence } \\
\hline 2007 & $1,92 \%$ & $0,52 \%$ & $0,70 \%$ & $0 \%$ & $0,17 \%$ & $0,52 \%$ \\
\hline 2008 & $2,20 \%$ & $0,73 \%$ & $0,73 \%$ & $0,44 \%$ & $0,14 \%$ & $0,14 \%$ \\
\hline 2009 & $3,17 \%$ & $1,21 \%$ & $0,70 \%$ & $0,60 \%$ & $0,60 \%$ & $0,15 \%$ \\
\hline \multicolumn{7}{|c|}{ Incidence } \\
\hline 2007 & 11 & 3 & 4 & 0 & 1 & 3 \\
\hline 2008 & 15 & 5 & 5 & 3 & 1 & 1 \\
\hline 2009 & 21 & 8 & 4 & 4 & 4 & 1 \\
\hline Average & 15,66 & 5,33 & 4,33 & 2,33 & 2 & 1,66 \\
\hline \multicolumn{7}{|c|}{ Myeloproliferatives Syndrome (MPS) } \\
\hline & MPS & $\begin{array}{c}\text { Chronic Myeloid } \\
\text { Leukemia }\end{array}$ & Polycythemia vera & $\begin{array}{c}\text { Thrombocytfemia } \\
\text { essential }\end{array}$ & \multicolumn{2}{|c|}{ Primary myelofibrosis } \\
\hline \multicolumn{7}{|c|}{ Prevalence } \\
\hline 2007 & $1,21 \%$ & $1,22 \%$ & $0 \%$ & $0 \%$ & \multicolumn{2}{|r|}{$0 \%$} \\
\hline 2008 & $1,32 \%$ & $1,32 \%$ & $0 \%$ & $0 \%$ & \multicolumn{2}{|r|}{$0 \%$} \\
\hline 2009 & $1,96 \%$ & $1,51 \%$ & $0,15 \%$ & $0,15 \%$ & \multicolumn{2}{|r|}{$0,15 \%$} \\
\hline \multicolumn{7}{|c|}{ Incidence } \\
\hline 2007 & 7 & 7 & 0 & 0 & \multicolumn{2}{|r|}{0} \\
\hline 2008 & 9 & 9 & 0 & 0 & \multicolumn{2}{|r|}{0} \\
\hline 2009 & 13 & 10 & 1 & 1 & \multicolumn{2}{|r|}{1} \\
\hline Average & 9,66 & 8,66 & 0,33 & 0,33 & \multicolumn{2}{|r|}{0,33} \\
\hline \multicolumn{7}{|c|}{ Acute Leukemia } \\
\hline & Acute & Acute lymphoblastic & Acute myeloblastic & \multicolumn{3}{|c|}{ Biclonal Acute leukemia } \\
\hline
\end{tabular}


Haematology International Journal

\begin{tabular}{|l|c|c|c|c|}
\hline & Leukemia & leukemia & leukemia & 0 \\
\hline 2007 & $0,87 \%$ & $0,52 \%$ & $0,35 \%$ & $0,15 \%$ \\
\hline 2008 & $1,17 \%$ & $0,44 \%$ & $0,59 \%$ & 0 \\
\hline 2009 & $1,51 \%$ & $1,06 \%$ & $0,45 \%$ & \\
\hline
\end{tabular}

Table 3: Incidence and compartmental prevalence of hematological malignancies.

\section{Discussion}

Our study was retrospective and descriptive. It covered a period of 03 years and consisted to determine the impact of toxic waste spilled to the incidence and prevalence of haematological malignancies in Côte d'Ivoire. 100 new cases of hematological malignancies were diagnosed in our department. There were 67 males and 33 females, a sex ratio of 2.03 close to that observed by Thiam D, et al. and Diallo DA who found respectively a sex ratio of 1.6 and $1.9[7,8]$. Although our study did not find a bibliography reporting a female predominance, several studies conducted in Africa and Europe had noted a male predominance [7-10]. Our patients were relatively young and corroborated the data of Ngolet LO, et al. in Brazzaville and Diagne I, et al. in Senegal $[11,12]$. Firstly, this age characterizes the haematological malignancies in sub-Saharan Africa where the means of diagnosis are limited. Secondly it could also be explained by the infection such as immunodeficiency virus and the Epstein Barr Viruses which are more observed at this age group in Africa. These viruses are known for their effects in the occurrence of haematological malignancies $[13,14]$. CML was the most common pathology in young adults. Regarding the places of residence, the majority of our patients lived in Abidjan (68\%), similar to data from N'dhatz CE, et al. in Abidjan [15].

However, the study of Guiegui CP, et al. reported a predominance of haematological malignancies in rural areas and is related to the use of pesticides in agropastoral activities. The study of N'dhatz CE, et al. covered the periods from 1999 to 2009, including the period of spilled of toxic waste in 2006. On the other hand, these observed facts could also be explained by the fact that the only clinical hematology department is located in Abidjan. This observation could also due to the impact of these toxic wastes from 2006. The result of our study noted an overall prevalence of hematological malignancies of $5.2 \%$. This prevalence was increasing from 2007 to 2009 with $4 \%, 4.3 \%$ and $6.64 \%$ respectively. N'Dhatz CE, et al. found a prevalence of $9.11 \%$ over 11 years [15]. In other study conducted by Tiam D, et al. in Senegal, the prevalence of haematological malignancies was estimated at $7 / 1000$ over 6-years period [7]. Lymphoproliferative syndromes were the most frequent with an annual frequency of $1.92 \%$ (2007); $2.20 \%$ (2008) and 3.17\% (2009). Then, myeloproliferative syndromes, in second position with annual frequency respectively of $1.21 \%$ (2007), $1.32 \%$ (2008) and 1.96\% (2009). As for acute leukemia, there were increasing prevalence of $0.87 \%$ (2007), $1.17 \%$ (2008) and $1.51 \%$ (2009). The same observation was made by Sawodogo D, et al. and Mounkaila B, et al. $[16,17]$. This could militate in favor of a potential role for toxic waste in the occurrence of hematological malignancies, especially with regard to its increasing nature since the spilling of this waste in the district of Abidjan. The analysis of toxic waste made by ICPC (International Center for Pollution Control) showed that it was a petroleum product related to gasoline associated with heavy metals, mercaptan and hydrocarbons [18]. As these products are individually haematotoxic in the medium and long term, it is not surprising that their associations potentiate this effect and lead to malignant diseases in this case malignant haematological diseases. The incidence of haematological malignancies since the advent of toxic waste is increasing. The peak frequency in 2009 was 44 cases, an average incidence of 33.33 news case/year. An incidence of 22.67 news case/year was found in Abidjan during the ten years from 1995-2004 by Sawodogo D, et al. while N'dhatz CE, et al. found 53, 36 news case/year and noted that the peak hospital prevalence was observed in 2006 with annual incidence of 81 news case. Between 2007 and 2009, lymphoproliferative syndromes had an annual incidence of 11, 15 and 21 news cases, respectively. For acute leukemias, there were 5, 8 and 10 news cases. As for myeloproliferative syndromes, we noted 7,9 and 13 news cases with CML the most common (89.65\%). Unlike the study of N'dhatz, et al. and Sawodogo D, et al. where Burkitt's lymphoma predominated $[15,16]$. This last observation could make toxic waste a risk factor for CML and acute leukemia, since the patients most affected by these two cancers came from areas close to toxic waste dumping sites. In addition to the favorable nature of toxic waste in the occurrence of hematological malignancies, we cannot demonstrate with certainty that some other risk factors mentioned in previous studies should not be underestimated and especially according to the sectors of activity. 


\section{Conclusion}

The impact of toxic waste in Abidjan has been an increase in the incidence and prevalence of haematological malignancies. Addition, other risk factors cannot be excluded apart from toxic waste.

\section{References}

1. Pierce DA, Shimizu Y, Preston DL, Vaeth M, Mabuchi K (1996) Studies of the Mortality of Atomic Bomb Survivors. Report 12, Part I. Cancer 1950-1990. Radiat Res 146(1): 1-27.

2. Fenet Rieutord M (1984) Influence de l'environement sur la diffusion des maladies tropicales: la trypanosomiase en Afrique centrale. Bull Ecol hum: 30-46.

3. World Health Organization (2002) Les effects des conditions environnementales sur la sante (No. EM/RC49/Tech Disc 2).

4. Clavel J (2016) Les leucémies de l'enfant. Les cahiers de la Recherche. Santé, Environment, Travail 8: 2930.

5. Bohand X, Monpeurt C, Bohand S, Cazoulat, A (2007) Dechets toxiques deverses a Abidjan (Cote-d'Ivoire) et consequences sanitaires. Med Trop 67(6): 620-624.

6. Kettani SEL, Azzouzi EM (2009) Prévalence de l'anémie chez une population rurale utilisant les eaux usées à des fins agricoles, Settat, Maroc. Biomatec Echo 3(6): 31-38.

7. Thiam D, Diop TM, Tallarmin F, Toure AO, Diakhaté L (1996) Epidemiology and therapy of malignant hemopathies in Senegal. Hematol Cell Ther 38(2): 187-191.

8. Diallo DA, Cissoko LS, Cissoko Y, Diallo Y, Baby M, et al. (2005) Epidémiologie actuelle des hémopathies malignes dans les services d'hématologie oncologie médicale et de médecine interne de l'hôpital du Point G, Bamako, Mali. Mali Med 20(4): 1-8.

9. Guyot-Goubin A, Clavel J (2009) Les hémopathies malignes. In: Sommelet D, et al. (Eds.), Epidémiologie des cancers de l'enfant, Springer Paris-Paris, 371.
10. Troussard X, Duchenet V, Cornet E, Mouchel D, Malet $M$, et al. (2009) Epidémiologie des hémopathies malignes en Basse Normandie Haematological malignancies: Incidence in Basse-Normandie, France, for 1997-2004. Rev Epidem Sant pub 57(3): 151-158.

11. Ngolet LO, Kocko I, Galiba Atipo TFO, Okouango Nguelongo OJD, Elira Dokekias A (2017) Incidence Hospitalière des Hémopathies Malignes de l'Enfant À Brazzaville. Health Sci Dis: 18(1): 66-69.

12. Diagne I, Diane G, Gaye Ly K, Sow D, Camara B, et al. (2002) Problèmes posés par la prise en charge des hémopathies malignes chez l'enfant au Sénégal. Dakar Med 47(1): 12-17.

13. Sitas F, Pacella Norman R, Carrara H, Patel M, Ruff P, et al. (2000) The spectrum of HIV-1 related cancers in South Africa. Int J Cancer 88(3): 489-492.

14. Gregersen $\mathrm{H}$, Vangsted AJ, Abildgaard N, Andersen NF, Pedersen RS, et al. (2017) The impact of comorbidity on mortality in multiple myeloma: a Danish nationwide population based study. Cancer Med 6(7): 1807-1816.

15. N'dhatz CE, Koffi KG, Ayemou R, Nanho Danho C, Alla $D$, et al. (2012) Prevalence Et Incidence Des Hemopathies Malignes Au Chu De Yopougon. Rev Int Sc Méd 3: 205-208.

16. Sawadogo D, Yapo AVDP, Sangaré M, Tolo A, Yayo Ayé M (2009) Caractéristiques épidémiologiques des patients atteints d'hémopathies malignes à Abidjan au cours de la décennie 1995-2004. J Afr Cancer 1(1): 4-10.

17. Mounkaila B, Toure IA, Gragnic G, Mounkaila I (1996) Hemopathies Malignes A Niamey A Propos De 90 Observations Sur 6 Ans. Med Af Noir 43 (8/9).

18. Adjiri O, Kouamé V, Niangoran CK, Soro G, Biémi J (2018) Déversement des déchets toxiques en Côte d'Ivoire: suivi de l'efficacité de l'opération de dépollution à partir d'indicateurs de pollutions résiduelles. Environnement, Risques \& Santé 17(2): 147-154. 